\title{
Professional exposure of medical staff WORKING IN ONE OF THE HOSPITALS OF THE MALOPOLSKA REGION BETWEEN 2013 AND 2016
}

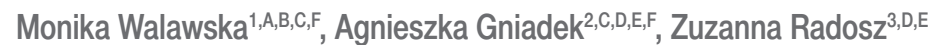

\author{
${ }^{1}$ Graduate of Faculty of Health Sciences, Jagiellonian University Medical College, Krakow, Poland \\ 2Department of Nursing Management and Epidemiology Nursing, Institute of Nursing \\ and Midwifery, Faculty of Health Sciences, Jagiellonian University Medical College, Krakow, Poland \\ ${ }^{3}$ Postgraduate student at Faculty of Health Sciences, Jagiellonian University Medical College, \\ Krakow, Poland \\ Authors' contribution: \\ A. Study design/planning • B. Data collection/entry • C. Data analysis/statistics • D. Data \\ interpretation $\bullet$ E. Preparation of manuscript $\bullet$ F. Literature analysis/search $\bullet$ G. Funds collection
}

\author{
Address for correspondence: \\ Agnieszka Gniadek \\ Department of Nursing Management \\ and Epidemiology Nursing \\ Institute of Nursing and Midwifery \\ Faculty of Health Sciences \\ Jagiellonian University Medical College \\ 25 Kopernika St. \\ 31-501 Krakow, Poland \\ e-mail: agnieszka.gniadek@uj.edu.pl \\ SUBMITTED: 28.11 .2019 \\ ACCEPTED: 11.12 .2019 \\ DOI: https://doi.org/10.5114/ppiel.2019.92538
}

\begin{abstract}
Introduction: Professional exposure of medical staff is an adverse event that might accompany the procedure of providing medical care.

Aim of the study: The objective of the study was the assessment of the incidence of professional exposure of medical staff providing medical care in one of the hospitals of the Malopolska region between 2013 and 2016.

Material and methods: In order to assess the exposure of medical staff an analysis of medical records from the period of 2013-2016 was carried out in the $5^{\text {th }}$ Military Clinical Hospital and Polyclinic in Krakow. The source of information was an Individual Card of Professional Exposure including the results of blood tests or tests for other potentially infectious fomites. The study included all reported cases of professional exposure that appeared during the examined period in the examined 400 -bed hospital.

Results: In the years 2013-2016 as many as 96 cases of professional exposure were observed, and they were more common in women $-70.8 \%$ and nurses $-50 \%$. The dominating source of professional exposure was the operating theatre. The activities that potentially pose the highest risk of professional exposure included patient's treatment or surgery as well as collecting material for medical tests. An obvious exposure was observed in $72.9 \%$ of the cases, and blood was the statistically most common exposure material.

Conclusions: Despite significant professional exposure to fomites, especially to blood, no hepatitis B virus (HBV), hepatitis $\mathrm{C}$ virus (HCV), or human immunodeficiency virus (HIV) infections were observed in the examined medical staff. Key words: professional exposure, medical staff, blood.
\end{abstract}

\section{INTRODUCTION}

In Poland there is no central register of professional exposure similar to the Exposure Prevention Information Network (EPINet), which is applied in many countries of the European Union and in the USA [1]. The lack of such a register makes is harder to assess the range of professional exposure that is an inherent risk factor while providing medical services. Although in scientific publications there can be found occasional reports about the incidence of needlestick injuries, cuts, or splashing during medical and nursing treatment, it is hard to determine which members of the medical staff are affected the most [2-5]. Moreover, available scientific publications describe this problem based on subjective diagnostic surveys, which present declared exposure rather than actual exposure [6-10]. Thus, the results describing the range of exposure may be underestimated or misinterpreted by researchers. In Poland there is a shortage of straightforward information about the range of exposure of medical staff to potentially infectious fomites depending on the place where medical treatment is provided, the character of the treatment, or correlation with particular medical units providing health care. It seems pointless to follow the procedure that used to be applied in the past, according to which any incidence of sharp injury was supposed to be registered in a special notebook, assuming that this particular person might develop a blood-borne 
disease in the future. Only a few people, for their own safety, registered the incidence of needlestick or other sharp injuries. These entries were not followed by any consequences or further action. In the course of time, hospitals gradually introduced instructions on preventing infections including viral hepatitis or human immunodeficiency virus (HIV); however, they referred mostly to the issues such as patient's safety or keeping records [11]. Nowadays, binding provisions of labour law require that health care units should provide their medical staff with a safe and hygienic working environment, protect them against adverse circumstances, and prevent the spread of infections resulting from needlestick injuries or cuts [12]. The Council Directive 2010/32/EU of 10 May 2010 on prevention of sharp injuries in the hospital and healthcare sector, aiming at improving the conditions of the working environment, is in force in Poland [13]. This directive is the legal basis of the Regulation of the Minister of Health of 6 June 2013 [14]. Despite clear legal regulations, the problem of professional exposure remains a complicated issue undervalued by medical staff, managerial staff, and other decision-makers. The number of unwanted incidents is still growing. Therefore, it is essential to assess the risk factors of professional exposure in order to understand the danger that follows and to apply effective preventive strategies [15].

\section{AIM OF THE STUDY}

The objective of the study was the assessment of the incidence of professional exposure of medical staff providing medical care in one of the hospitals of the Malopolska region.

\section{MATERIAL AND METHODS}

An analysis of medical records from the period 2013-2016 was carried out in the $5^{\text {th }}$ Military Clinical Hospital and Polyclinic in Krakow. The study included all reported cases of professional exposure that appeared during the examined period in the examined 400-bed hospital, both in surgical and non-invasive treatment wards. The hospital provided medical treatment in the operating theatre, hospital accident and emergency unit, dental clinic and in other units including neurology, cardiology, general surgery, pulmonology, otolaryngology, ophthalmology, traumatology, orthopaedics, internal diseases, intensive care, anaesthesiology, neurosurgery, and an isolation unit.

The source of information for the analysis was an Individual Card of Professional Exposure including the results of blood tests or tests for other potentially infectious fomites. The data obtained from these records included: the date of the exposure, practised profession, the ward in which the exposure took place, results of post-exposure test, type of fomites, procedure during which the exposure took place, exposed part of the body, applied means of personal protection, applied post exposure procedure, personal details of the exposed person, as well as information about their vaccination and level of anti-HBs.

Formal consent of the hospital administrator was obtained in order to examine medical records and carry out the study. Medical records were analysed following the rules of personal data protection and the ethical principles for medical research defined by the Declaration of Helsinki. All documents examined in this analysis were complete and included all incidents of professional exposure recorded in the hospital between 2013 and 2016. Statistical analysis of the obtained results was conducted. Differences between variables were verified by means of $\chi^{2}$ test of independence. The choice of nonparametric test was made according to the nominal character of variables. The level of significance was assumed at $p<0.05$, and statistical calculations were carried out with the application of IBM SPSS Statistics 20 software.

\section{RESULTS}

As many as 96 cases of professional exposure to blood or other potentially infectious fomites were reported in the examined hospital in the period between 2013 and 2016. Three people reported to have been exposed twice, so the exact number of medical staff exposed to potentially infectious fomites was 93. In 2013 only 12 cases of exposure were reported ( $12.5 \%$ of all 96 reported cases), in 2014 the number of incidents reached 27 (28.1\% of all 96 reported cases), in 2015 the number reached 24 (25\% of all 96 reported cases), whereas in 2016 as many as 33 cases were reported, which made up $34.4 \%$ of all the cases reported between 2013 and 2016. In 2014 the number of reported exposures was more than twice as many as in 2013. A significant increase could also be observed in 2016 when the number of exposures was almost three times higher than in 2013. The differences in the incidence of exposure in particular years was statistically significant ( $p=0.0208$ ). Professional exposure was more common in women $70.8 \%(n=68)$ than in men $29.2 \%(n=28)$. No statistically significant correlation was observed between the number of cases reported in particular years and the gender of medical staff (Table 1).

The group consisting of nurses turned out to be the one that was exposed to infectious fomites the most, at 50\% ( $n=48)$, whereas doctors who experienced such exposures made up $36 \%$ of all medical staff examined $(n=34)$. The other medical staff members who reported exposure worked as paramedics $7 \%(n=7)$, medical assistants 6.3\% $(n=6)$, or a physiotherapist $1.0 \%(n=1)$ (Figure 1$)$. 
Table 1. The number of reported cases of exposure between 2013 and 2016 and the respondents' gender

\begin{tabular}{|c|c|c|c|c|c|c|}
\hline \multirow[t]{3}{*}{ Year } & \multirow{2}{*}{\multicolumn{2}{|c|}{ Number of reported cases }} & \multicolumn{4}{|c|}{ Gender } \\
\hline & & & \multicolumn{2}{|c|}{ w } & \multicolumn{2}{|c|}{$M$} \\
\hline & $n$ & $\%$ & $n$ & $\%$ & $n$ & $\%$ \\
\hline 2013 & 12 & 12.5 & 9 & 9.4 & 3 & 3.2 \\
\hline 2014 & 27 & 28.1 & 18 & 18.7 & 9 & 9.4 \\
\hline 2015 & 24 & 25.0 & 19 & 19.8 & 5 & 5.2 \\
\hline 2016 & 33 & 34.4 & 22 & 22.9 & 11 & 11.4 \\
\hline \multirow[t]{2}{*}{ Total } & 96 & 100.0 & 68 & 70.8 & 28 & 29.2 \\
\hline & \multicolumn{2}{|c|}{$p=0.0208$} & \multicolumn{4}{|c|}{$p=0.7028$} \\
\hline
\end{tabular}

$n$-number of cases, $W$-women, $M-$ men

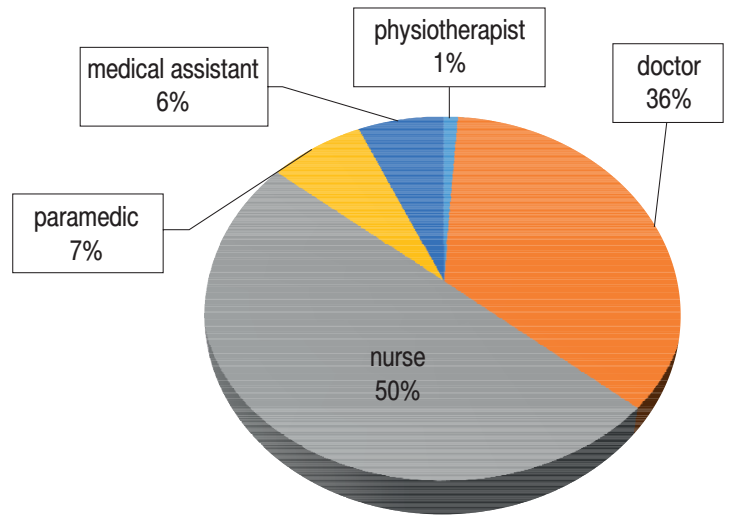

Figure 1. Exposure incidence and respondents' profession

No statistically significant correlation was found between the workplace and the number of exposure cases in particular years. There were some slight differences, which indicated that in 2013 exposure cases were more common in medical staff other than doctors and nurses (physiotherapists, paramedics, and medical assistants). In turn, in 2014 doctors experienced professional exposure more frequently than nurses or other medical staff, and in both 2015 and
2016 such exposure was more common in nurses than in doctors or other medical staff (Table 2).

Professional exposure cases were most common in the operating theatre $-24 \%(n=23)$, and slightly fewer cases were observed in intensive care and the anaesthesiology ward $12.5 \%(n=12)$ or the cardiology ward $11.5 \%$ ( $n=11)$. Medical staff working in the hospital accident and emergency unit reported 9.4\% of exposure cases $(n=9)$, and only occasional cases were observed in other wards. No significant differences were observed in the number of exposure cases in particular years as far as various hospital wards are concerned (Table 3).

Most professional exposure cases $81.3 \%(n=78)$ took place during day shifts, between 7 a.m. and 7 p.m. In a few rare cases $18.8 \%(n=18)$ exposure was observed during night shifts, between 7 p.m. and 7 a.m. No correlation was observed in particular years between the number of exposure cases and their time. Slight differences implied that in 2015 exposure was more common between 7 p.m. and 7 a.m. (33.3\%), whereas in 2016 between 7 a.m. and 7 p.m. (35.9\%).

The incidence of needlestick injuries was the most frequent reason of professional exposure, at $79.2 \%(n=76)$, and less frequently it was splashing $15.6 \%(n=15)$ or cuts $5.2 \%(n=5)$. Every medical staff

Table 2. The number of reported cases of exposure between 2013 and 2016 and the respondents' profession

\begin{tabular}{|c|c|c|c|c|c|c|c|c|c|c|}
\hline \multirow[t]{3}{*}{ Year } & \multicolumn{10}{|c|}{ Profession } \\
\hline & \multicolumn{2}{|c|}{ Physiotherapist } & \multicolumn{2}{|c|}{ Doctor } & \multicolumn{2}{|c|}{ Nurse } & \multicolumn{2}{|c|}{ Paramedic } & \multicolumn{2}{|c|}{ Medical assistant } \\
\hline & $n$ & $\%$ & $n$ & $\%$ & $n$ & $\%$ & $n$ & $\%$ & $n$ & $\%$ \\
\hline 2013 & 1 & 100.0 & 6 & 17.6 & 2 & 4.2 & 1 & 14.3 & 2 & 33.3 \\
\hline 2014 & 0 & 0.0 & 12 & 35.3 & 12 & 25.0 & 3 & 42.9 & 0 & 0.0 \\
\hline \multirow[t]{2}{*}{ Total } & 1 & 100.0 & 34 & 100.0 & 48 & 100.0 & 7 & 100.0 & 6 & 100.0 \\
\hline & \multicolumn{10}{|c|}{$p=0.1106$} \\
\hline
\end{tabular}

n-number of cases 
Table 3. The number and percentage of reported cases of exposure between 2013 and 2016 in particular units

\begin{tabular}{|c|c|c|c|c|c|c|c|c|c|c|}
\hline \multirow[t]{3}{*}{ Unit } & \multicolumn{10}{|c|}{ Number of reported cases in total and in particular years } \\
\hline & \multicolumn{2}{|c|}{ Total } & \multicolumn{2}{|c|}{2013} & \multicolumn{2}{|c|}{2014} & \multicolumn{2}{|c|}{2015} & \multicolumn{2}{|c|}{2016} \\
\hline & $n$ & $\%$ & $n$ & $\%$ & $n$ & $\%$ & $n$ & $\%$ & $n$ & $\%$ \\
\hline Operating theatre & 23 & 24.0 & 0 & 0.0 & 10 & 43.5 & 5 & 21.7 & 8 & 34.8 \\
\hline Pulmonology & 3 & 3.1 & 0 & 0.0 & 0 & 0.0 & 1 & 33.3 & 2 & 66.7 \\
\hline Neurology & 4 & 4.2 & 1 & 25.0 & 1 & 25.0 & 2 & 50.0 & 0 & 0.0 \\
\hline Otolaryngology & 6 & 6.3 & 1 & 16.7 & 1 & 16.7 & 1 & 16.7 & 3 & 50.0 \\
\hline Ophthalmology & 1 & 1.0 & 0 & 0.0 & 0 & 0.0 & 0 & 0.0 & 1 & 100.0 \\
\hline General surgery & 6 & 6.3 & 1 & 16.7 & 1 & 16.7 & 0 & 0.0 & 4 & 66.7 \\
\hline Traumatology and orthopaedics & 5 & 5.2 & 0 & 0.0 & 0 & 0.0 & 3 & 60.0 & 2 & 40.0 \\
\hline Internal diseases & 8 & 8.3 & 3 & 37.5 & 4 & 50.0 & 0 & 0.0 & 1 & 12.5 \\
\hline Intensive care and anaesthesiology & 12 & 12.5 & 2 & 16.7 & 3 & 25.0 & 4 & 33.3 & 3 & 25.0 \\
\hline Cardiology & 11 & 11.5 & 1 & 9.1 & 2 & 18.2 & 3 & 27.3 & 5 & 45.5 \\
\hline Neurosurgery & 3 & 3.1 & 1 & 33.3 & 0 & 0.0 & 2 & 66.7 & 0 & 0.0 \\
\hline Isolation unit & 1 & 1.0 & 0 & 0.0 & 0 & 0.0 & 1 & 100.0 & 0 & 0.0 \\
\hline Dental clinic & 4 & 4.2 & 1 & 25.0 & 2 & 50.0 & 1 & 25.0 & 0 & 0.0 \\
\hline Hospital accident and emergency unit & 9 & 9.4 & 1 & 11.1 & 3 & 33.3 & 1 & 11.1 & 4 & 44.4 \\
\hline Total & 96 & 100.0 & & & & & & & & \\
\hline
\end{tabular}

$n$ - number of cases

member who experienced professional exposure in the form of needlestick injuries or cuts was wearing safety gloves at that time. These types of exposure usually took place while taking samples for tests and/ or during a treatment/surgery, in each case the percentage reached $21.9 \%(n=21)$. In $18.8 \%$ of cases the exposure circumstances were different, including administering anaesthetics, stopping bleeding, inserting stitches, nursing, or rehabilitation. Professional exposure was less common during injections, at $14.6 \%$ ( $n=18)$; inserting/removing PVC (peripheral venous catheters), at $12.5 \%(n=13)$; or cleaning, at $10.4 \%$ $(n=10)$ (Figure 2).

Blood was reported to be the most frequent infectious material $86.5 \%(n=83)$, whereas in $5.2 \%$ of cases $(n=5)$ it was respiratory system secretion and in another $5.2 \%$ of cases the fomites were not identified. There were also single cases of exposure to human tissue, some unidentified body fluid, or other fomites $-1.0 \%(n=1)$ in each case. The findings show that blood was a significantly more frequent infectious material in particular years, although in 2013 fluids and secretions other than blood were also a significant infectious factor (Table 4).

In 70 cases $(72.9 \%)$ the exposure was obvious, and in another $19.8 \%$ of cases $(n=19)$ it was only a potential exposure. There were some cases of splashing fomites on healthy skin $5.2 \%(n=5)$, or no information about the type of exposure was given $2.1 \%(n=2)$. No statistically significant correlation was found between the type of professional exposure and its incidence in particular years.

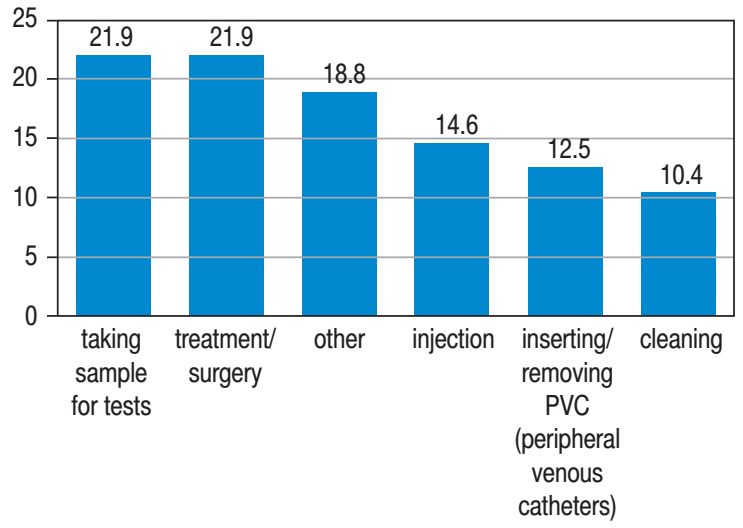

Figure 2. Exposure incidence and activities during which it took place

All the people who experienced professional exposure had taken a complete cycle of hepatitis B vaccination 36 months prior to this undesired event. In $68.1 \%$ of respondents who experienced exposure $(n=62)$ the level of anti-HBs exceeded $100 \mathrm{IU} / \mathrm{I}$, less frequently, in $27.5 \%$ of respondents $(n=25)$, it ranged between 10 and $100 \mathrm{lU} / \mathrm{l}$. Only in a few cases was the level of anti-HBs antibodies lower than $10 \mathrm{lU} / \mathrm{l}$.

No statistically significant differences were found in particular years in the level of anti-HBs antibodies in the respondents who experienced exposure. In almost all respondents examined on the day of exposure negative test results were obtained as far as antiHBs and anti-HIV antibodies are concerned, and only in one case was the anti-HBs antibodies test positive. 
Table 4. Exposure incidents and the type of infectious fomites

\begin{tabular}{|c|c|c|c|c|c|c|c|c|}
\hline \multirow[t]{3}{*}{ Type of infectious fomites } & \multicolumn{8}{|c|}{ Number of exposure incidents in particular years } \\
\hline & \multicolumn{2}{|c|}{2013} & \multicolumn{2}{|c|}{2014} & \multicolumn{2}{|c|}{2015} & \multicolumn{2}{|c|}{2016} \\
\hline & $n$ & $\%$ & $n$ & $\%$ & $n$ & $\%$ & $n$ & $\%$ \\
\hline Blood & 7 & 58.3 & 26 & 96.3 & 23 & 95.8 & 27 & 81.8 \\
\hline Other & 5 & 41.7 & 1 & 3.7 & 1 & 4.2 & 6 & 18.2 \\
\hline \multicolumn{9}{|c|}{$p=0.0052$} \\
\hline
\end{tabular}

The serological status of patients who were the source of exposure to hepatitis B antigen was negative in most cases, at $91.7 \%(n=88)$. Positive results were observed in only $2.1 \%$ of patients $(n=2)$, in a few cases the source of exposure was unknown $5.2 \%(n=5)$, and in one case no consent to collect blood samples for hepatitis B virus (HBV), hepatitis C virus (HCV), HIV tests was obtained from the patient who was the source of exposure. In the majority of patients, $80.2 \%$ $(n=77)$, hepatitis C antigen was negative as well. Moreover, the HIV antigen tests turned out to be negative for the vast majority of patients who were the source of exposure $90.6 \%(n=87)$. Positive results of the test were observed in only three patients $-3.1 \%$ of all cases. Three members of medical staff were qualified for HIV infection prevention procedure. This procedure was applied in two cases (a doctor and a nurse) because the third person (a paramedic) rejected the offer of pharmacological prevention of HIV infections. None of the respondents who reported the incidence of exposure to biological material in the examined period of time were infected with $\mathrm{HBV}, \mathrm{HCV}$, or HIV.

\section{DISCUSSION}

Between 2009 and 2016 as many as 1462 cases of occupational diseases that affected medical staff and social workers were recorded in the Central Register of Occupational Diseases. In 2016 this percentage was $42.6 \%$ lower than in 2009 . The average annual incidence rate in these years reached 26.3 per 100,000 employees [16]. Although a decrease in the number of reported cases of occupational diseases has been observed in recent years in Poland, hepatitis is still likely to remain the most frequent occupational disease in the group of medical staff. The main infectious factor is in this case exposure to blood or other infectious fomites, and almost every other case of an occupational disease reported by medical staff refers to nurses [16]. This study also shows that exposure was most frequent in nurses and then in doctors, who made up one third of all exposed employees. These findings are confirmed by Szczypta et al., according to whom the most numerous group that experienced exposure were nurses (67.8\%) and then doctors (29\%) and then other medical staff (1.5\%). However, the studies by Gańczak et al. carried out in obstetrics and gynaecology wards showed that doctors were more susceptible to professional exposure (76.2\%) than nurses (57.3\%) [3]. It is worrying that both doctors and nurses frequently fail to report the incidence of professional exposure even if they realise what consequences may follow the lack of post-exposure treatment [17-19]. It is reassuring, though, that the study of Garus-Pakowska and Górajczyk conducted in a group of health care workers showed that the period of employment coincides with the need to protect against professional exposure such as needlestick injuries (OR 1.33, 95\% Cl: 0.99-1.78) [10]. Unfortunately, this study belongs to a group of only a few similar ones which emphasise the positive prevention measures applied by medical staff, because the other sources point out that professional exposure which is not reported at all makes up $27 \%$ to $80 \%$ of all incidents of sharp injuries that are experienced while providing medical service [9]. In the examined hospital the incidence of exposure was more common during day shifts (7 a.m. to 7 p.m.) $-81.3 \%$ than at night $-18.8 \%$. The most frequent exposure locations included the operating theatre $(24 \%)$ and intensive care and anaesthesiology ward (12.5\%). It might have resulted from the fact that most medical procedures were conducted just in this time and place. The studies carried out by Pelc in the Hospital in Przeworsk show that in the years 2010-2013 in a group of 31 health-care workers who reported an incidence of exposure nearly a half of all cases happened in the operating theatre [20]. Similar results were obtained by Kocur et al. in the City Hospital in Zabrze in the years 2006-2015, where also the operating theatre was the place where the incidence of exposure was the most frequent [4]. Similarly, the studies of Szczypta et al. also show that medical treatment facilities were the main place where the incidence of exposure was observed $(72 \%$ of the cases of exposure reported in this hospital) [2]. On the other hand, Garus-Pakowska and Szatko discovered in their studies that it was not only the staff working in medical treatment facilities that were vulnerable to exposure, but also health-care workers employed in non-invasive treatment wards [19]. 
In Poland the incidence of sharp injuries is quite frequent in numerous health-care facilities. According to the studies conducted by Pelc [20], as many as 20 out of 31 cases of exposure were connected with medical procedures such as inserting/removing PVCs (peripheral venous catheters), and taking blood samples for tests or injections, which in the studies by Szczypta et al. made up 77\% [2]. In this study sharp injuries made up $79.2 \%$ of all exposure cases, and fingers (67.7\%) and hands (15.6\%) were the most exposed body parts. Similarly, in the study by Paruzel et al. fingers and hands were the most vulnerable to exposure, at $75.4 \%$ and $11.5 \%$, respectively [21].

It is widely acknowledged that the risk of sharp injuries can be minimised by wearing protective gloves. It has been proven that gloves may form a barrier in the event of needlestick injuries and block off as much as $86 \%$ of blood when a solid needle is used and $50 \%$ of blood in the case of a hollow-bore needle injury. Protective gloves are also a preventive measure against direct contact with potentially infectious material [22]. In this study all the respondents declared that they were wearing protective gloves at the time of exposure. However, the findings of the study by Gańczak et al. were more worrying because even though every ninth respondent declared that they were wearing gloves at the time of contact with potentially infectious material, every $20^{\text {th }}$ respondent admitted not doing it at all [3]. Another survey conducted in a group of 487 health-care workers in 26 Polish hospitals showed that nurses, more often than others, for example doctors or paramedics, took their protective gloves off in order to facilitate medical procedures. The difference was statistically significant $(p=0.036)$. Moreover, the tendency to take off their protective clothing significantly coincided in the examined group with a longer period of employment (OR 1.16, 95\% Cl: 0.995-1.36) [10]. Unfortunately, Jonczyk et al. in their study also discovered that the longer the nurses' period of employment, the more vulnerable they were to injuries [6].

In the authors' own study, it was difficult to determine the direct cause of professional exposure, but it seemed to be the most common while collecting material for laboratory tests or during surgeries. Nevertheless, the results of other studies show that a direct cause of professional exposure may be not only negligence or mistakes while performing the procedure but also a so-called sense of urgency $[23,24]$. This term is defined as a sense of pressure to perform the task as quickly as possible due to work overload and/ or understaffing. According to Jonczyk et al., professional exposure resulted from rushing [10], whereas, according to Piatek, its causes included rushing and tiredness, understaffing, and too many patients who had to be looked after by one nurse during her/his shift [25]. Mehrad et al. claim that there is a correlation between psychosocial factors including stress at work and vulnerability to injuries in nursing staff [26]. Garus-Pakowska and Górajski noticed that apart from rushing (31.4\%) and lack of attention in healthcare workers (27\%), also unexpected behaviours of patients may be the results of injuries during medical procedures [10]. In recent years in Poland a significant shortage of medical staff has been observed, and consequently, an inadequate number of nursing and medical procedures that the staff must perform while looking after patients [27, 28].

In 1993 the European Parliament approved a law that recognised hepatitis virus as the most serious risk factor for medical staff. Since 1989 the number of vaccinated health-care workers has been gradually growing, and obligatory vaccination has been introduced [29]. In the examined hospital all healthcare workers who experienced exposure had taken a complete three-dose cycle of hepatitis $B$ vaccination 36 months prior to this undesired event, and their level of antibodies was sufficient.

There are no HCV or HIV vaccines, and therefore it is essential to take proper preventive measures such as reporting the cases of professional exposure in order to introduce proper post-exposure prevention procedures [2].

Medical staff should do their duties and follow procedures in a responsible and reliable way. They should not be afraid of taking care of patients who are infected with HIV, HBC, or HCV or those who are carriers of blood-borne pathogens. They should not be afraid that patients are not obliged to inform the medical staff about their being carriers of some infectious diseases. This concern and anxiety are not always connected with the knowledge that medical staff possess. Knowledge does not always have a significant influence on the change of attitude towards self-protection against infections, including the act of reporting the incidence of exposure. It might result from the fact that the procedure of reporting exposure is highly formalised or, which is even more likely, from the common belief shared by medical staff that professional exposure is an inherent element of their work and reporting it is a waste of time. Inefficiency of obligatory training sessions carried out among medical staff, faulty methods of teaching or social approval and assent given when the incidents of exposure are not reported are also the reasons of improper behaviour of medical staff as far as reporting undesired events is concerned.

\section{CONCLUSIONS}

Despite significant professional exposure to fomites, especially to blood, no HBV, HCV, or HIV infections were observed in the examined medical staff. 
It is vital to introduce safe equipment to medical and nursing treatment so as to eliminate any professional exposure.

Although professional exposure is most frequently observed in nurses and doctors, the other medical staff (including the cleaning staff) should also be properly educated as far as professional exposure to infections is concerned.

\section{Disclosure}

The authors declare no conflict of interest.

\section{References}

1. The Exposure Prevention Information Network. https:// www.medicalcenter.virginia.edu/epinet/ about epinet.html

2. Szczypta A, Różańska A, Bulanda M. Analiza ekspozycji zawodowej pracowników medycznych w latach 1998-2013 na patogeny przenoszone drogą krwi na przykładzie szpitala o profilu zabiegowym. Med Pr 2015; 65: 723-732.

3. Gańczak M, Szych Z, Karakiewicz B. Ocena zawodowego narażenia na zakażenie HBV, HCV i HIV u personelu oddziatów ginekologii i położnictwa. Med Pr 2012; 63: 11-17.

4. Kocur E, Śliwa-Rak B, Grosicki S. Analiza ekspozycji zawodowych na krew zarejestrowanych w Szpitalu Miejskim w Zabrzu w latach 2006-2015. Przegl Epidemiol 2016; 70: 603-615.

5. Braczkowska B, Kowalska M, Zejda J. WZW C wśród pracowników służby zdrowia w województwie śląskim w latach 1996-2003. Przegl Epidemiol 2005; 59: 661-670.

6. Jończyk A, Szczypta A, Talaga-Ćwiertnia K. Zdarzenia ekspozycyjne $w$ czasie udzielania świadczeń medycznych przez personel pielęgniarski. Przegl Epidemiol 2018; 72: 371-381.

7. Prażak Z, Kowalska M. Wyposażenie stanowiska pracy pielęgniarki w środki ochrony indywidualnej jako element profilaktyki w związku z narażeniem na materiał biologiczny. Problem Pielęg 2017; 25: 43-48.

8. Kołpa M, Grochowska A, Gniadek A, et al. Poziom wiedzy personelu medycznego szpitala o przenoszeniu zakażeń drogą kontaktową - wynik badania ankietowego. Przegl Epidemiol 2015; 69: 615-618.

9. Smoliński P, Serafińska S, Gładysz A. Ocena niedoszacowania częstości ekspozycji na materiał biologiczny wśród pracowników polskiej służby zdrowia - analiza prospektywna. Med Pracy 2006; 57: 507-516.

10. Garus-Pakowska A, Górajski M. Behaviors and attitudes of polish health care workers with respect to the hazards from blood-borne pathogens: a questionnaire-based study. Int J Environ Res Public Health 2019; 16: 891.

11. Czapska E. Problem zakłuć - sytuacja w ocenie fachowca i praktyka. Magazyn Pielęgniarki i Położnej, wydanie specjalne 2015; 2-3.

12. Świątkowska B. Nowe instrumenty prawne w zakresie profilaktyki zranień pracowników medycznych. Forum Zakażeń 2014; 3: 185-189

13. Dyrektywa Rady 2010/32/UE z dnia 10 maja 2010 r. w sprawie wykonania umowy ramowej dotyczącej zapobiegania zranieniom ostrymi narzędziami w sektorze szpitali i opieki zdrowotnej zawartej między HOSPEEM a EPSU.

14. Rozporządzenie Ministra Zdrowia z dnia 6 czerwca 2013 r. w sprawie bezpieczeństwa i higieny pracy przy wykonywaniu prac związanych z narażeniem na zranienie ostrymi narzędziami używanymi przy udzielaniu świadczeń zdrowotnych. Dz. U.2013 poz. 696
15. Garus-Pakowska A. Narażenie personelu medycznego na materiał potencjalnie zakaźny. Ochronne działania poekspozycyjne. Forum Zakażeń 2016; 7: 25-31.

16. Świątkowska B, Hanke W. Choroby zawodowe w Polsce w 2016 roku. Med Pr 2018; 69: 643-650.

17. Serafińska S, Smoliński P, Gładysz A. Krytyczna ocena rejestracji ekspozycji zawodowych związanych z naruszeniem ciągłości tkanek oraz wynikających z tego konsekwencji wśród pracowników polskiej służby zdrowia. Med Pr 2006; 57: 439-450.

18. Braczkowska B, Kowalska M, Beniowski M, et al. Zawodowa ekspozycja pracowników służb medycznych na wirus HIV w województwie śląskim. Med Pr 2010; 61: 315-322.

19. Garus-Pakowska A, Szatko F. Ekspozycje przezskórne personelu medycznego. Med Pr 2011; 62: 473-480.

20. Pelc M. Pielęgniarki poszkodowane w miejscu pracy. Magazyn Pielęgniarki i Położnej 2013; 12: 22-28.

21. Paruzel D, Braczkowska B, Kowalska M. Ekspozycja zawodowa na krew i materiał potencjalnie zakaźny pracowników Okręgowego Szpitala Kolejowego w Katowicach w latach 2007-2012. Forum Zakażeń 2014; 5: 263-269.

22. Szarpak Ł, Kurowski A. Czy podwójne rękawiczki chronią przed kontaminacją podczas kaniulacji naczyń krwionośnych? Badanie prospektywne randomizowane. Med Pr 2014; 65: 271-278.

23. Patrician PA, Pryor E, Fridman M, et al. Needlestick injuries among nursing staff: Association with shift-level staffing. Am J Infect Control 2011; 39: 477-482.

24. Clarke SP, Rockett JL, Sloane DM, et al. Organizational climate, staffing, and safety equipment as predictors of needlestick injuries and near-misses in hospital nurses. Am J Infect Control 2002; 30: 207-216.

25. Piątek A. Błędy i wykroczenia w praktyce zawodowej pielęgniarek i położnych a bezpieczeństwo pacjentów. Zdrowie Publiczne 2005; 115: 465-470.

26. Mehrdad R, Atkins EH, Sharifian SA, Pouryaghoub G. Psychosocial factors at work and blood-borne exposure among nurses. Int J Occup Environ Med 2014; 5: 32-39.

27. Aiken LH, Douglas MS, Bruyneel L, et al. Nurses' reports of working conditions and hospital quality of care in 12 countries in Europe. Int J Nurs Stud 2013; 50: 143-153.

28. Przewoźniak L, Kózka M, Cisek M, et al. Organizacja i zakres badań RN4CAST (Registered Nurse Forecasting) dotyczących planowania zatrudnienia w pielęgniarstwie w Polsce. Zeszyty Naukowe Ochrony Zdrowia. Zdrowie Publiczne i Zarządzanie 2012; 10: 266-276.

29. Wilczyńska U, Szeszenia-Dąbrowska N, Sobala W, et al. Choroby zawodowe stwierdzone w Polsce w 2010 roku. Med Pr 2011; 62: 347-357. 